\title{
Legal regulation of Natural Resources as a Category of Environmental Resources for Providing Economic Activity on the Example of Ukraine
}

\author{
Daria Piddubna ${ }^{1}$, Illia Karakash ${ }^{2}$
}

\begin{abstract}
:
Every citizen has the right to safe natural resources. In Ukraine, this right is fixed at the level of the Constitution of Ukraine and special legal acts. The right to natural resources determines the citizen's right to: land resources; water resources; forest resources; flora and fauna; mushrooms; berries; atmospheric air. Ecological nature of natural resources is associated with the provision of various types of safety: environmental, energy, water, food, biological, genetic, and in aggregate - national. To implement the above, it is necessary to amend the regulatory framework in Ukraine on the following positions: responsibility (both from the side of officials and from the side of economic entities); system verification of the state of natural resources; ban on burning stubble, forest strips; strengthening of responsibility for the destruction of water facilities, cutting of plant resources, for the introduction of pesticides, for the implementation of atmospheric emissions and discharges into water objects; introduction of organic farming. The main thing - the issue of environmental friendliness of natural resources is characteristic not only for Ukraine, but also for the whole world. From their status depends on the suitability of life for every inhabitant of the planet, as well as the state of the planet itself.
\end{abstract}

Keywords: natural resources, an ecological resource, the constitutional rights of citizens, land resources; water resources; forest resources; flora and fauna; mushrooms; berries; atmospheric air.

\section{Introduction}

The right to safe natural resources is determined, among other things, as it is customary to call constitutional rights of citizens. They include diverse constituents, which in their totality form the environment.

The right to natural resources is available to every person living on earth. These natural resources must be safe and fit for use, and therefore be environmentally friendly. In order to better regulate public relations on the direct use of natural resources and to ensure environmental friendliness, the development and adoption of an appropriate regulatory framework aimed at the conservation, restoration of natural resources that provide the life of all mankind was carried out.

The above, justifies the use of the term «ecological resource», which determines the quality of the environment. Thus, in the presence of the characteristics of natural resources as an ecological resource, it is possible to speak with confidence about their

| ${ }^{\mathrm{Ph}} . \mathrm{D}$. in Law, head of the Department of Civil Law Disciplines of Donetsk Law Institute of the Ministry of Internal Affairs of Ukraine.

${ }^{2}$ Doctor of Law, professor, professor of the Department of Ecological, Land, Agrarian Law of the National University "Odessa Law Academy". 
safety. At the same time, the essence of such security will be determined not only for others, but also for the resources themselves.

Under the condition of availability of an ecological resource - it is possible to carry out any kind of economic activity, including organic farming, which involves the use of exclusively ecological natural resources. The scope of its possible implementation determines a significant amount of natural resources that can be used bits, namely: land, water, air, vegetable and animal resources, mushrooms, berries, etc. In this case, it is necessary to differentiate the legal regime regarding natural resources and the legal regime in depending on the possibility of their use, which transforms natural resources into natural objects.

Legal regulation of natural resources, including their environmental, is carried out at the level of the Constitution of Ukraine, codified acts, special laws and a number of other normative legal acts. The main and special law of Ukraine, which has a speciallygeneral meaning, is the Law of Ukraine «On the Protection of the Natural Resources» (Verkhovna Rada of Ukraine, 1991). Analysis of its legal norms provides an opportunity to assert sufficient development, but statistical data in the field of environmental indicators of natural resources reflects negative indicators. In connection with this, the question arises if the law regulates why the practice has such indicators. And the answer lies in the question of responsibility for the created, as defined by other normative acts, and the general acquaintance gives grounds to speak about the insignificant amount of responsibility or in general about its absence. It is precisely this indication and strict implementation that should become a further direction of improving Ukrainian legislation in the field of natural resources - an ecological resource. After all, the life and health of all the inhabitants of the country, and on the whole and the planet, depend on the state of the environment.

\section{Current trends in the practical implementation and legal regulation of certain natural resources in Ukraine through international cooperation.}

The issue of preserving and restoring natural resources should take place through a series of appropriate actions. One of these is the direction of bioenergy.

Thus, in Ukraine, in cooperation with the European Bank for Reconstruction and Development, it is planned to launch a bioenergy program in 2019. Such a decision is due to the fact that the diversity of natural resources of Ukraine provides the opportunity to create not only bioenergy stations, but also to expand the approach, namely to include an interconnected chain - «from field to end consumen» (EBRD launches bioenergy program in Ukraine). The implementation of this project is planned to be realized through the receipt of cash in the amount of 80 million euros, and the solution to this was the position that Ukraine is an agrarian country, and a large number of production balances remains in the fields, and they can be directed to use by processing. In the direction of the need to review the relation to the state of the soil, as the main natural resource in the field of agricultural production, the verification of soil health, which should be carried out not only with standard soil tests, but also indicators of measurement of «breathing» (Scientists suggest to determine the "pulse" of the soil). Scientists explain this embodiment with a fairly simple mechanism for its 
implementation, in particular: «the health of the soil is determined by the chemical, physical and biological properties ... most manufacturers have experience in the implementation of elementary soil tests for $\mathrm{pH}$, as well as are able to directly draw conclusions about the quality of the fertile layer in the field, judging by its structure» (Scientists suggest to determine the "pulse" of the soil). However, the possibilities of science allow us to establish a description of the soil biology, including the activity of soil microorganisms. In this direction, the well-known developments of American scholars, who made a proposal - checking "the breath of the ground." This position was proposed by Rick Heiney - "a scientist from the US Department of Agriculture at Texas University of A \& M; the right to carry out such research belongs to accredited specialists» (Scientists suggest to determine the "pulse" of the soil). According to the researchers, the essence and procedure of the test are as follows: «The test is carried out using a 24-hour test on the release of CO2 in 3-day or 7-day periods. Moreover, the latest tests are not popular among agrarians because of the high cost. The test can record concentrations of CO2 emissions by 30, 60, 90 or 120 ppm. The higher the value, the more active the soil microbes that process the nutrients to create a natural fertilizing plant roots. And the more intense emissions, the better the "pulse» of the soil»» (Scientists suggest to determine the "pulse" of the soil).

In addition to attracting the attention of scientists to the possibility to study the structure of the soil, it is necessary to take into account the fact that it is formed and varies depending on how it is handled and directly applied to it. The latter, namely, the introduction, can be divided into two directions: the first, the introduction of agrochemicals, pesticides, fertilizers directly to the soil, and the second - the cultivation of planted vegetation directly, and access to vegetation, as a consequence of cultivation of neighboring land in the aviation way. In connection with the above mentioned, under the threat of uncontrolled distribution of agrochemicals, pesticides, and fertilizers fall into the land plots that constitute both a natural resource and a natural object as well as flora - also in the sense of natural resources and natural resources. and the relevant rights of citizens, as defined by the Basic Law of the country and detailed in a special legal framework.

Confirmation of this, may lead to situations that have already arisen and characterize this, in the world. Thus, «in the United States of America, seven farms have sued Monsanto, BASF, DowDuPont and Pioneer, which produce herbicides and GM seeds. Farmers claim a claim to Dicambe herbicide (a chemical that destroys weeds), which in their words damaged crops on adjacent fields, seeded with genetically modified species resistant to chemicals» (In the United States, they embarked on a dicamba and introduced additional restrictions). Also included is the position on which: «Last year, Missouri and Arkansas announced a 120-day ban on spraying dikams in the summer. According to Missouri University researcher Kevin Bradley, referred to by the Department of Agriculture of Missouri, 3 million acres (1.2 million hectares) were affected by herbicides» (In the United States, they embarked on a dicamba and introduced additional restrictions). At the same time, the fact that Monsanto's representatives say, and, moreover, acknowledge, are interesting, and in particular: «the substance enters the adjacent fields when the herbicide is incorrectly introduced or when counterfeit analogs of dicambi are used. It takes time to learn new technologies. Three 
quarters of users did not comply with the requirements on the label, - said vice president of Monsanto on the global strategy of Scott Partridge» (In the United States, they embarked on a dicamba and introduced additional restrictions). Positions regarding the practically impossible observance of all the requirements prescribed in the instructions of application were determined, which in its totality led to the development and introduction into the Recommendations for the use of the relevant products, in particular Dikambi, the need for the "Limited use", recommending the introduction of a certain limit on processing at high temperatures air, as well as the terms of use, and explanation must be subjected to: sensitive / susceptible crops; the buffer zones should be determined by 360 degrees rather than on the leeward side (In the United States, they embarked on a dicamba and introduced additional restrictions).

The next fact that we draw attention and which also has an impact, and directly concerns natural resources and natural objects, is characteristic of the territory of Ukraine, related to chemicals and treatment. Chemistry and processing provides an opportunity to define a wider range of both factors that contribute to both application and exposure. In particular: «more than $10 \%$ of the world market of pesticides is illegal. Business sales of counterfeit or counterfeit plant protection products are among the top ten most profitable. In Ukraine, the price of the issue - 2 billion dollars» (Weigh on billions). In addition, the impact on the components of the natural chain is also determined. So, with the situation that has arisen and has become widespread throughout Ukraine, it is possible to state with regard to bees: «the holding of the "burial bee" campaign, based on the model of its European colleagues under the walls of the Cabinet of Ministers of Ukraine, with the requirement to bring to criminal liability for the use of poor quality pesticides, and the number appeals to the State Service of Ukraine for Food Safety and Consumer Protection increased at times» (Weigh on billions). The beekeepers and representatives of the Beekeepers Union of Ukraine state: «the death of at least 35-40 thousand bee farmers, and the cost of beekeepers reached 100-120 million hryvnias. The reason for the situation was the use of poor quality pesticides in fields often of unknown origin» (Weigh on billions). This is the situation that arose in 2018 in Ukraine, according to the deputy director of the State Enterprise «Scientific Center for Preventive Toxicology, Food and Chemical Safety named after academician L.I. Bearer of the Ministry of Health of Ukraine» Oleksandra Kravchuk due to improper use of chemicals and lack of sufficient communication between farmers and beekeepers (Weigh on billions). The role of several factors was also identified: «ignorance of the rules of handling at spraying, non-compliance by manufacturers' instructions and the amount of counterfeit and counterfeit pesticides and agrochemicals that have literally flooded the market this year, as the market for counterfeiting of plant protection products on the territory of Ukraine is from 20 to $30 \%$, and in retail trade - reaches $80-90 \%$, and according to experts' estimates, the market for plant protection products is $\$ 2$ billion» (Weigh on billions). In addition, specialists in this direction are talking about the intensification of the illegal circulation of illegal pesticides and agrochemicals, which is confirmed: «in late June, the Security Service of Ukraine blocked the supply channel from China for the protection of plants of unknown origin, which were imported to Ukraine under the guise of licensed European drugs. Law enforcers seized a lot of 139 tons of pesticides in the total amount of almost 18 million hryvnia. It is known that 
smuggled goods were sold throughout Ukraine. In fact, the perpetrators traded drugs that did not undergo compulsory state registration in Ukraine and, accordingly, were not allowed to be imported. In the process of customs clearance, false data was submitted to the declaration, allegedly that plant protection products are manufactured in the territory of the European Union and have state registration. And customs and environmental authorities deliberately did not see discrepancies in preparations that were imported under the guise of quality plant protection products» (Weigh on billions). Representatives of the State Service of Ukraine for Food Safety and Consumer Protection see problems in the moratorium on the implementation of planned state supervision measures, including on plant protection. Such a position contributed to the development of amendments to a number of regulatory acts, namely: «On pesticides and agrochemicals» (Verkhovna Rada of Ukraine, 1995), "On the protection of plants» (Verkhovna Rada of Ukraine, 1998), «On licensing of types of economic activity» (Verkhovna Rada of Ukraine, 2015), «About beekeeping» (Verkhovna Rada of Ukraine, 2000), the Criminal Code of Ukraine (Verkhovna Rada of Ukraine, 2001). However, practitioners in this area of activity determine the following: «the proposed mechanism for regulating the problems of mass death of bees and fake through the introduction of trade licenses will not have any effect. The Law of Ukraine «On the Licensing of Types of Economic Activities» provides that an entity that has a license is obliged to adhere to the licensing conditions ... and provides an exhaustive list of requirements that are mandatory for the licensee» (Weigh on billions). That is, in essence, the proposed changes are only a double check of business entities, which is a violation of the principles of economic activity. In addition, attention is drawn to the fact that persons carrying, storing, selling smuggled means of plant protection will not specify the actions to be carried out in the manner prescribed for legal economic activity, and the control mechanism enters the very last. In connection with this, the proposed mechanism is not a way to combat smuggling, falsification, etc., and requires new, weighted, systemic mechanisms.

Possibility of coverage and consideration for the purpose of further regulation is the position of experts on a particular issue. In particular: «the real mechanism for resolving the problem is the interaction of all the authorized bodies. And the central role in this should be occupied by the State Fiscal Service. As the current legislation provides that only authorized plant protection products authorized and tested in Ukraine are allowed. Therefore, the authorized border control authorities should pay more attention to substances that are being imported and to control their further use» (Weigh on billions). From the position of the coordinator of the programs of development of the Food and Agriculture Organization of the United Nations (FAO) Michael Malkov: «the spread of counterfeit and falsified pesticides occurs in two ways: through the import of counterfeit drugs from abroad and through the domestic production of counterfeit pesticides» (Weigh on billions). Also, consideration should be given to the fact not only of the import of ready-made drugs of inadequate quality, but also the import of substances, which are then mixed and prepared already on the territory of Ukraine, that is, it is about raw materials. Among the possible options for such a situation, it is possible to support existing positions, in particular: «low level of experience of customs inspectors, low potential of customs laboratories, absence of risk profiles for pesticides in the existing system of customs risks management, zero level of international customs cooperation. In 
addition to issues with the customs and the lack of audits over the last four years, another channel for the dissemination of counterfeit pesticides is the gaps in the waste management system: the lack of environmentally sound recycling of counterfeit pesticides, temporary storage for detained counterfeit drugs, in addition, the system of container recording is not working properly» (Weigh on billions).

Another problem in this area is the availability and handling of pesticides that are characterized by expired shelf life, but instead of utilization, they can fall into the process of use and are simply under the «open ain», since no recycling mechanism is foreseen. Moreover, the recycling mechanism is not for both substances and containers. Official statistics determine the increase of indicators for the management of solid domestic waste in the country during 2015-2017 years. In particular: the collection of solid domestic wastes, in 2017 -included 822 settlements; the number of garbage sorting lines, in 2017, were determined as an indicator of 25; the quantity of landfills that do not meet the requirements of environmental safety - 1347; the number of landfills and landfills in 2017 is set at 5434; the number of unauthorized landfills is also determined by the increased indicator, namely 30184. In general terms, indicators show a tendency to increase rather than to reduce and introduce new approaches.

The unsettled issue of utilization of packaging of pesticides generates its free circulation in the market for the sale of goods. The reason for such consequences can be defined: «lack of access from farmers to new innovative drugs with higher quality active substances. After the adoption in late 2016 of the amendments on the need to confirm the mandatory state registration of pesticides in the country where they are produced, samples of the latest drugs can not be imported into our country for state tests. It only aggravated the problem with a fake, because the innovative materials of the new generation, which are much more difficult to counterfeit than well-known «old» preparations, do not come to the market. ... The Ministry of Environment and Natural Resources of Ukraine does not grant permits for the export of chemical waste abroad for their disposal at specialized plants» (Weigh on billions). On the path to change, individuals working in this area of business determine certain positions with which they can agree, as they are similar to international requirements, in particular: «introduction of licensing of import of active substances as separate components; when importing a pesticide - companies must provide a complete list of permit documents, test results and inspections» (Weigh on billions).

From these positions it is seen that in order to change the situation that does not occur at the level of state authorities, as it should be in accordance with the Constitution of Ukraine and a number of other normative legal acts, the society must be involved, in particular by claiming their claims, defending rights, etc. . The measure of radical advocacy of its rights is, of course, the last act, but given the immutability, the sustainability of environmental and not only environmental rights and freedoms in Ukraine, action remains only a way to exert their rights and freedoms. It starts to happen in Ukraine. In particular: on the way to changing the situation with bees, beekeepers came to a rally under the Cabinet of Ministers of Ukraine to require farmers to be held accountable for the use of low-quality chemicals (Beetle coffin under the Cabinet: people went to the rally because of the massive death of insects). 
The next fact confirming the problem of environmental friendliness of natural resources is the appeal of the residents of Ukraine to the President of Ukraine with a request to ban farmers from using pesticides in field airfreight processing. Such an act is explained: «none of the certified Ukrainian laboratories controls the use of pesticides by Ukrainian agrarians. Profile control bodies - the State Service of Ukraine for Food Safety and Consumer Protection and the State Ecological Inspection of Ukraine - only check the availability of documents for the use of certain or other poison chemicals, environmentalists add. There is no government control over the actual content of pesticides in water, air and soils, which pesticides are used by agribusinesses and in what amount, whether they are lawfully imported into Ukraine and are not forbidden to use or prolonged. And people, and especially children, with symptoms of chemical poisoning, are turning to medical care» (Poisoning of Ternopil: ecologists called on the President to ban the air treatment of fields with chemicals).

It is possible to give attention: «facts of uncontrolled use of pesticides by Ukrainian agrarians ... as a result, about 300 people were injured simultaneously, among them 100 are children. All of them are residents of the Ivan-Pust village, which is in the Ternopil region. In a few days the controllers established the culprit of the event - the company "Kernel". According to the controlling bodies, the company unlawfully sprayed the fields with chemicals at a distance of $550 \mathrm{~m}$ from residential development. In addition, herbicides «Hurricane Fort» containing glyphosate were detected in sunflower samples taken from the company. In March 2015, the International Agency for Research on Cancer (IAWR) stated that there are «some indications» that indicate the likelihood of cancer in humans when using glyphosate herbicide, and classified the drug as carcinogenic» (Poisoning of Ternopil: ecologists called on the President to ban the air treatment of fields with chemicals).

In this direction, it is possible to point out the international position that will be: «the 47-year-old Austrian fruit-growing farmer has been using a powerful chlorpyrifos insecticide on its trees in the province of Carinthia. At that time, flowers were still blooming, which attracted bees. Due to the carelessness of the farmer more than 50 colonies of bees that belonged to two neighboring beekeepers died. The court found him guilty of «deliberate harm to the environment», given the farmer's experience and the fact that he knew about the consequences of spraying this substance. He was sentenced to one year in prison, four months would be without probation. Also, the farmer will pay compensation. The convict wants to appeal» (The farmer destroyed 50 colonies of bees. For this he was imprisoned).

There may be a question: why exactly about bees, about pesticides, agrochemicals, aviation processing of fields is indicated within the limits of the question of natural resources - ecological resources in the field of human rights. The explanation for this is quite simple: the right to suitable natural resources and natural objects is determined at the level of the Basic Law of Ukraine, other specialized and general normative legal acts, but the practical situation reflects the most negative and unsatisfactory state and in order to change it is necessary to pay attention attention, lighting, etc .. In addition, this - it is also an element of the natural chain. All its components are interconnected and complement each other. If any activity is violated, everyone else is in danger. Yes, bees - they are necessary both for the conduct of 
economic activity and for that plant world, which is defined as a natural object. Processing of fields by ground or air means - the flora, as an economic value, gets into influence, in particular the immediate owner, and the neighboring owners who do not have the desire to cultivate their cultivation; as well as the plant world - as a natural object, which simply grows in forest belts as an example, but they are of local importance, are considered safe and can be used by any citizen for the purpose of realizing their recreational, for example, rights. As a result of such actions, insects, which are also representatives of the natural object, as well as air, atmospheric air, are also exposed, and consequently there is an integrated influence.

Against this background, taking into account Ukraine's agrarian potential, including in the field of plant growing, medicine, mushroom, berry, fruit and vegetable, etc., it is possible to determine: «over the course of 9 months of this year, Ukraine has exported medicinal raw materials to 8.8 million dollars. ... besides, the typical mistake of this business in Ukraine is that manufacturers devote only $5-10 \%$ of their time to marketing and sales» (The market for Ukrainian medicinal plants is estimated at 500 million USD per year). This is a reflection of the prospect of development that has the potential to be realized in the territory of Ukraine, and those who are planning to engage in or are already involved in this area should be concerned not only with production, but also with sales markets, will be realization - there will be mechanisms for improving product quality, inventing ways of its implementation, establishment of environmental friendliness, etc. In this direction, the state authorities should not be isolated, there should be state support and assistance through mechanisms of simplified access to international markets and tax mechanisms, ensuring environmental friendliness of natural resources, and in aggregate - the implementation of the corresponding rights of citizens will be ensured.

\section{Legal regulation of the activity of state bodies and determination of some positions of the economic mechanism on the way of ensuring the environmental friendliness of natural resources.}

As already noted, the environmental quality of natural resources is influenced both by atmospheric air and air, since Ukraine has the Air Code of Ukraine and the Law of Ukraine «On the Protection of Atmospheric Air» ((Verkhovna Rada of Ukraine, 1992). There is a number of new directions of influence and pollution factors. It is possible to note that emissions from industrial enterprises, from thermal power plants, during combustion of vegetation residues, etc. - reflect the exceeding of all standards, which is another important problem. For example: «Pridneprovskaya TPP violates environmental legislation, poisoning about a million poison every day. As a result, the environmental inspection carried out an unscheduled inspection of the compliance of the entity with the requirements of the environmental legislation. Inspecting the entire territory was prohibited by environmental inspectors, but some of the major violations were still detected. From the beginning of the year, the company carried out excessive emissions of pollutants into the air. This is evidenced by the excess of indicators of nitrogen oxides, sulfur dioxide, suspended solids. Also, environmental inspectors recorded an excess of carbon monoxide in waste gases at Unit 8. At the same time, more 
than 50 types of industrial waste are not accounted for in full. Sand that is polluted with sewage treatment plants, sludge from the cleaning of rain gutters, sludge's from the cleaning of steam boilers, etc. - everything is not inventoried, therefore, where it goes farther is unknown. During the preliminary inspection, it was established that there is no meter of waste sewage taken from the population at the enterprise in the city sewage network. Documents on elimination of violations did not provide inspectors. Therefore, how much waste water flows into the city sewage, nobody knows. Employees of the thermal power plant are not the first to hide the documents. They did not provide any information on the implementation of environmental modernization of treatment equipment and the establishment of a system of irregular monitoring of waste gases. Hid and documents on the reconstruction of the collector and the introduction of an automatic monitoring system of the impact of industrial activities on the state of surface and groundwater. Problems in the Pridneprovskaya thermal power plant, even with a license for water supply and sewage activities. She ended last year. Therefore, it is not clear, on the basis of which the establishment of tariffs for these services» (Overregulatory emissions of pollutants and overdue license: result of inspection of Pridneprovskaya TPP).

In this direction it is possible to state another, but similar information. According to the indexes of the integrated index of atmospheric air pollution in the cities of Ukraine in the first half of 2018, it was determined that the general level of atmospheric air pollution in the cities of Ukraine (for CIAA - a complex index of atmospheric air pollution) in the first half of 2018 was estimated as high, and compared with the same period of the past year, it rose slightly (from 7.1 to 7.6) due to the growth of phenol content. Among the factors of high level of air pollution is determined by a significant average concentration of formaldehyde, nitrogen dioxide, phenol, hydrogen fluoride, carbon monoxide, suspended solids. The largest indicators were determined in Lutsk - 12.2; Donetsk region - 9,0; Odessa - 13.1; Mykolayiv - 9.9; Kryviy Rih - 8.8; Dnieper - 11,8; Cherkasy - 6,8; other cities are characterized by an indicator of 3.8; 6.5; 5.7 and others.

By changing this state, it is possible to indicate the position in the cities of Lviv and Zhytomyr, Chortkiv and Kamyanets-Podilsky to switch to green energy by 2050 . This position is internationally recognized, in particular: «according to the results of the Global Climate Summit in San Francisco, the transition to 100\% renewable energy by 2050 was announced by leaders from more than 100 major cities and regions, including Los Angeles, Tokyo and Mexico City. The state of California has set itself an even more ambitious goal: to make an energy transition by 2045» (No pipes and smoke. Can Lviv and Zhytomyr become completely green until 2050).

The justification for this transition is the following: «cities are responsible for $80 \%$ of the world's gross domestic product and most of the final energy consumption is still met by fossil fuels. According to the international consulting firm MsKinsey, by 2030, the total investment in urban infrastructure, including buildings, engineering networks and transport, will amount to $\$ 53$ trillion. This is twice as much as the expected volume of investments in the energy production and supply sector, which, according to the International Energy Agency, can be 25.2 trillion dollars. Obviously, the future of the global economy in general and the energy sector in particular will determine 
the city itself. The lifeblood of the cities is caused by a large part of the greenhouse gas emissions, so they also depend a little more than the economy: the state of the atmosphere, the pace and extent of climate change, the rise of the global ocean, the rate of loss of biodiversity and the availability of freshwater on the planet. Climate change is threatened by increased waves of heat, an increase in the frequency and intensity of hurricanes and floods. As a result, more than 200 million people from the most vulnerable regions can become climatic refugees and create migration pressures which will be hard to sustain for less afflicted cities. To prevent or minimize a significant part of these risks, more and more cities are heading for complete decarbonization and support the goal of keeping global warming at 1.5 degrees. This movement is gaining momentum after the Global Climate Summit and the statements of the leaders of the world's leading cities. Cities have purely economic motives for post-carbon restructuring. According to the United Nations Development Program (UNDP), the global economy will increase by $10 \%$ by 2050 if ambitious greenhouse gas emission reductions are taken in line with the objectives of the Paris Agreement. Renewable energy and energy efficiency are key tools for achieving this goal. According to IRENA, they are capable of providing 90\% GHG emission reductions in energy related sectors, including transport, industry, urban development and utilities» (No pipes and smoke. Can Lviv and Zhytomyr become completely green until 2050). Taking into account the above, which explains the need for such a transition, it is considered in Ukraine as a need for the introduction of a certified system for the purchase of energy, which once again proves the need to implement the established expression «to start with itself» and to change the economic dimension to the human being, which will be to help preserve the environment both for themselves and for future generations.

Another confirmation of the need to start with each citizen, namely his responsible attitude, is the position on the burning of plant remains. For today, burning is prohibited, but ... Citizens, business entities, enterprises, in a word all - forget about it for some reason. Thus, as a characteristic feature of the biological properties of the leaves is the accumulation of all harmful emissions from the atmosphere, the persons once again subjected to heat treatment at high temperatures by combustion, which again causes the air to enter the atmosphere of harmful substances and does not envisage the impact on the environment, its components and the same person, but such actions are committed by the person themselves, and the result leads to the conclusion - the person is still where to live, albeit a variety of diseases, let contaminated natural resources, etc., but the main thing - the restoration of natural resources, the cure of the human body, etc.. These are the issues that are a priori understandable, but certainly not for the people of Ukraine.

Currently, in this area, it is possible to meet the reports of local authorities on a series of actions on the issue of prosecution of burning foliage (Penalty for fire: in the Dnieper check the private sector). On the one hand, it seems to be true, but where does the activity of these bodies work, when large agricultural companies burn stubble after harvest in the summer when all forest bands are burned out, as the means of warning, namely flushing by no one, are the result of a burnt desert, but the forest belt is not just planting trees is protection against water, wind erosion, a partial element in the formation of humus, the location of animals, insects, vegetable, mushroom world, etc. The question 
arises: where in such moments there is activity of local self-government bodies, state executive bodies, including inspections, departments, departments etc. At the same time, the work of local self-government bodies is relevant to the population, it is good, but where does control control of enterprises, agricultural firms, corporations, etc., or control and penalize those strata of the population who will not stand up for their rights, because of ignorance of the law, their rights, and sometimes not having the financial capacity to appeal to a court for the protection of their rights. And this is exactly the problem for Ukraine, this is exactly the direction in which the state and every one of its inhabitants should work. An even more interesting aspect is the use of drones to identify persons burning leaves within their own territory. Unacceptable actions are taken as indicative and subject to the alleged fulfillment of relevant international requirements, often accompanied by the need to execute or demonstrate performance in order to receive another international monetary tranche. Sometimes, in the absence of systematic control over environmental issues, due to lack of personnel. To confirm this, we can state: «within the framework of the reform of the sphere of environmental oversight, personnel recruitment of specialists is ongoing to five pilot districts established in place of the liquidated territorial bodies of the State Ecological Inspectorate, which worked in 10 regions of Ukraine. ... In addition to the metropolitan area, there are also 27 vacancies from 94 required in the Central District (Poltava and Cherkasy oblasts), 100 of 112 provided by the staffing of the Crimean-Black Sea district (based on the liquidated State Inspections in Sevastopol, Crimea, Azov-Black Sea State Inspection and State Inspection of the Northwest Black Sea Region), there are 35 vacancies from 134 in the Poles'k District. The selection of personnel for the pilot Carpathian district (IvanoFrankivsk and Chernivtsi region) will start after the completion of the appropriate procedures for creation. ... As you know, on May 31, 2017, the Government of Ukraine approved the Concept for reforming the system of state supervision (control) in the field of environmental protection. According to the Concept, it is planned to form 10 interregional districts instead of the 27 existing territorial bodies of the State Inspection. At this stage, the process of launching 5 pilot districts continues» (The State Environmental Inspectorate is looking for staff in pilot districts).

The next and decisive fact, to which a certain degree has already been discussed, is the financial justification of any activity. It does not overlook the scope of the use of natural resources. However, in Ukraine, financial support is directed only to certain people, and not to everyone who carries out the corresponding economic activity in the agrarian sector. So, we note: «the draft State Budget for 2019 provides for subsidies in support of the agrarian sector in the amount of almost 7 billion UAH. Most of them will not be small farmers, but big agricultural holdings, in particular, Myronivsky Hliboproduct and Ukrlandfarming. ... For comparison, in the USA, the average size of state support per manufacturer is less than 1 thousand dollars (about 25 thousand UAH), in the EU countries - 6,1 thousand euros (up to 200 thousand UAH). In Ukraine, this indicator is 53 times higher than in the EU, and about 7 thousand times more than in the USA» (The size of subsidies of Ukrainian agroholdings is 53 times higher than in the EU and 7 thousand times more than in the USA).

It is more expedient to speak not about state support of agrarian activity, but about the provision of opportunities for unimpeded product sales at the international 
level and support and promotion at the national level. As a positive trend towards this, there is the opening of a «Peasant Bazaar» in Sumy, which has the opportunity to sell its products grown on its own sites (Sumy opened "Peasant bazaar").

The above reflects the attention and assistance to realization of the place of realization of production of own production and this is a good position, which should be supported and implemented in each region, each region, each district, city, settlement and even rural areas. Another line of financial support should take place in this direction. In particular, it is possible to already find information on the reduction of the value added tax rate for fruit and berry products. It is noted that «in July, the Verkhovna Rada registered the draft law «On Amendments to the Tax Code of Ukraine for Reducing the Value Added Tax for Horticultural Products, Mushrooms and Viticulture» № 8570, which propose to reduce the value added tax rate on fruitful -profitable products grown in Ukraine from $20 \%$ to $7 \%$... The association assures that the reduction of the tax rate will be an effective replacement of the "special regime of value added tax" and last year's subsidies, which will allow the industries producers to save $13 \%$ of the money they had to pay value added tax, which amount to more than 1 billion USD for use in the development of production, reducing costs and actually reduce government spending on unnecessary administration registers recipients of subsidies. ... For example, in the developed agricultural countries of the EU, when taxing agricultural commodities, in most cases, a reduced rate, which is at least twice as much, and sometimes three times lower than the standard, applies: Spain - 4\%; France - 2.1, 5.5, 10\%; Ireland - 4.8\%; Italy - 4\%; Luxembourg - 3\%. Under such conditions, the manufacturer automatically accumulating a tax credit sends it for its own development. Such a system provides predictability and planning of production activity and the competitiveness of Ukrainian producers on the European market, and also allows to significantly reduce the cost price of fruit and berry products and consumer prices for its (Reduction of the VAT rate to $7 \%$ for fruit and berry products will give impetus to the industry - Ukrsadprom).

At the same time, it should be noted that the State Fiscal Service of Ukraine: «began preparations for the introduction of a law on the introduction of a «one stop shop» mechanism at the customs and optimization of control procedures when moving goods across the customs border of Ukraine. In particular, work is under way to create a single state information portal «Single Window for International Trade», which will simplify the issuance of permits during customs clearance. The customs officers will check the permits that were previously verified by officials of the State Environmental Inspectorate, and the border guard authorities were authorized to control the level of radioactive contamination of vehicles and cargoes. At the same time, sanitary and epidemiological and ecological control of goods during their movement through the customs border of Ukraine are canceled, and during the export of goods outside the customs territory of Ukraine, state control types will not be carried out at all» (DFS will simplify international trade through a one-stop shop).

To a certain extent, the direction towards the achievement of the above should be not only a voluntary decision of officials of the state legislative, executive, judicial branches of power, but also the corresponding developed legal and regulatory framework. In this direction, the Ministry of Ecology and Natural Resources of Ukraine are carrying out certain work, in particular regarding the adoption of the State 
Environmental Policy Strategy until 2030 (Ostap Semerak: "The Strategy for State Environmental Policy adopted until the year 2030 adopted in the first reading").

Acquaintance with the position of representatives of state executive bodies provides an opportunity to state not only the need to meet the requirements of the European Union, but also the need to bring the regulatory framework to compliance, which is determined by the need to provide a safe, suitable environment for the population.

Other positions in a particular direction are holding regular meetings, which are carried out at the European level on the environmental sphere. Nevertheless, it is great to have such meetings to resolve relevant issues, but there are occasions where such meetings again lead to the fact that Ukraine receives certain funds for changing environmental issues and good when they are provided on an irrevocable basis. Another situation when these funds need to be repaid in the future, because they need to be taken from somewhere, and this, in turn, may involve an increase in the tax base, an increase in taxes that will be applied to the citizens of Ukraine in the overwhelming majority (Ostap Semerak: "Ukraine, Georgia and Moldova will receive financial assistance from the EU for the development of the environmental sphere").

All defined actions that must be carried out in the legal and regulatory direction regarding economic, social and other related issues should take place with the obligatory consideration of the position regarding the need for the formation of the ecological consciousness of every inhabitant of Ukraine, regardless of age, gender, position etc. Indeed, there are even indicators that determine ecological consciousness in Ukraine and in the European Union: 5 similarities and differences (Ecological consciousness in Ukraine and in the EU: top 5 similarities and differences). According to the results of the survey, it is interesting that for ecologists and Ukrainians, ecological issues are important, which are attracting attention, when it comes to practical implementation of actions in the direction of changing the situation regarding ecology; negative indicators characterize Ukrainians.

\section{Conclusions}

Thus, the priority should be to change the approach among civil servants of special bodies in the field of ecology, because some norms are prescribed for today, but no one enters into force. In the future, state policy should aim at forming the ecological consciousness of Ukrainian citizens and responsible, careful attitude to natural resources. The defining axiom should be natural resources - ecological natural resources. The regulatory framework needs to be detailed, simplified and unified on the example of the European Union.

\section{References}

Law of Ukraine "About the protection of the environment", 25.06.1991 No 1264-XII // http://zakon.rada.gov.ua/laws/show/1264-12 [Accessed 28.12.2019]. 
EBRD launches bioenergy program in Ukraine // http://greenfund.com.ua/2018/10/19/yebrr-zapustyt-vukrayini-programu-z-bioenergetyky/?fbclid=IwAR2JcL7T4k_hMPEx5I789e-

J0AI6b7iUawTkpbhJICVlC6BwI-XPiw5IdDE [Accessed 28.12.2019].

Scientists suggest to determine the "pulse" of the soil // https://growhow.in.ua/naukovtsi-proponuyutvyznachaty-puls-

gruntu/?fbclid=IwAR0EtRJQthzzNgaXCdr5rFPFQMD2uqWVCpqeS2TvhqzvpsecQdGPaaeWh D4 [Accessed 28.12.2019].

In the United States, they embarked on a dicamba and introduced additional restrictions // https://growhow.in.ua/u-ssha-vzyalys-za-dykambu-i-vvely-dodatkovi-obmezhennya/ [Accessed 28.12.2019].

Weigh

on billions

https://www.epravda.com.ua/projects/poleua/2018/10/16/641568/?fbclid=IwAR3_50bAmRko U2ORaicu4hw6c90HuKRqxUQomk6sMjAap6Tf010u_9B93lc [Accessed 28.12.2019].

Law of Ukraine "On pesticides and agrochemicals" 02.03.1995 № 86/95-VR // http://zakon.rada.gov.ua/laws/show/86/95-вp [Accessed 28.12.2019].

Law of Ukraine "On the protection of plants" 14.10 .1998 p. № 180-XIV // http://zakon.rada.gov.ua/laws/show/180-14 [Accessed 28.12.2019].

Law of Ukraine "On licensing of types of economic activity" 02.03.2015 p. № 222-VIII // http://zakon.rada.gov.ua/laws/show/222-19 [Accessed 28.12.2019].

Law of Ukraine "About beekeeping" 22.02.2000 p. № 1492-III // http://zakon.rada.gov.ua/laws/show/1492-14 [Accessed 28.12.2019].

Criminal codex of Ukraine 05.04.2001 p. № 2341-III. Information from the Verkhovna Rada of Ukraine. 2001. № 25-26. Art. 131.

Beetle coffin under the Cabinet: people went to the rally because of the massive death of insects // https://ecology.unian.ua/salvationspecies/10287972-bdzholina-truna-pid-kabminom-lyudiviyshli-na-miting-cherez-masovu-zagibel-komahvideo.html?fbclid=IwAR3uJzeB5Dyn3hwG1g0gDMzKKZrAwiisGve-3uIn8_AdO1hgnqSBpizF28 [Accessed 28.12.2019].

Poisoning of Ternopil: ecologists called on the President to ban the air treatment of fields with chemicals // https://www.unn.com.ua/uk/news/1755294-otruyennya-ternopolyan-ekologi-zaklikaliprezidenta-zaboroniti-aviaobrobku-poliv-khimikatami?fbclid=IwAR1XOS3Cig13Lb6zY7zzMkLiJgaa4bMY7_qVfEmveSQOAjXctk9u9FgDHo [Accessed 28.12.2019].

The farmer destroyed 50 colonies of bees. For this he was imprisoned // https://espreso.tv/news/2018/09/27/fermer_znyschyv_50_koloniy_bdzhil_za_ce_yogo_uvyazn yly?fbclid=IwAR1TnhVTv3F_1wmP_aN4fufmP3EzOHMP8On-30LS05IPf5eXX1qZ_JVhZk [Accessed 28.12.2019].

The market for Ukrainian medicinal plants is estimated at 500 million USD per year // https://growhow.in.ua/rynok-ukrayinskyh-likarskyh-roslyn-otsinyuyetsya-v-500-mln-grn-narik/?fbclid=IwAR0sIlQmsdvZ5OZnwKdVU22jVpgXk4U4C09g83u_Ma47UucA91UL05Ly-DM [Accessed 28.12.2019].

Law of Ukraine "About the protection of atmospheric air" 16.10 .1992 p. № 2707-XII // http://zakon.rada.gov.ua/laws/show/2707-12 [Accessed 28.12.2019].

Over-regulatory emissions of pollutants and overdue license: result of inspection of Pridneprovskaya TPP // http://dniprograd.org/2018/10/17/nadnormativni-vikidi-zabrudnyuyuchikh-rechovin-taprostrochena-litsenziya-rezultat-inspektsii-pridniprovskoites_72329?utm_source=dlvr.it\&utm_medium $=$ facebook\&fbclid=IwAR3wI_1wzBsEgGMgvaGjs HqHYJRy7pKgZWq94G6IZ-iPyGrI72Y4Z2gKzok [Accessed 28.12.2019].

No pipes and smoke. Can Lviv and Zhytomyr become completely green until 2050 // https://www.epravda.com.ua/publications/2018/10/17/641648/?fbclid=IwAR13ngygSIPryFanyZAzwgWHcCAqNWffn-BhcAT1VdU39TQLPYZpmxYw38 [Accessed 28.12.2019].

Penalty for fire: in the Dnieper check the private sector // https://dpchas.com.ua/dnepropetrovskayasolyanka/shtraf-za-kostyor-v-dnepre-proveryayut-chastnyy-

sektor?fbclid=IwAR3llCRGpB79JVB9P4-tKdenoIXJpdHcGHP5FMvNtUjx4EO_UUq1wkfaAtI [Accessed 28.12.2019]. 
The State Environmental Inspectorate is looking for staff in pilot districts // https://www.ukrinform.ua/rubric-society/2556234-derzavna-ekoinspekcia-sukae-kadri-u-pilotniokrugi.html?fbclid=IwAR0cdau-bCTHo7HydYN045hW-afB9nme1VeWlCHoTnXHuLWgmUC41JjwCI [Accessed 28.12.2019].

The size of subsidies of Ukrainian agroholdings is 53 times higher than in the EU and 7 thousand times more than in the USA // https://zernovik.com/news/rozmir-dotacij-ukrainskih-agroholdingiv-v53-razi-vishhij-nizh-v-ies-ta-v-7-tis-raziv-bilshij-nizh-vssha/?fbclid=IwAR1SEIOrwy2sjtOUUMAJITPx3wVX35GGafHu6z6Yn8RhRLK8FxYsPALCp PE [Accessed 28.12.2019].

Sumy opened "Peasant bazaar" // http://tv.sumy.ua/u-sumah-vidkryly-selyanskyjbazar/?fbclid=IwAR1lFm0SHIFskePN6YTjpWShmJe19aMYEq_jxq02qeA9Xcma832T4sX5bfs [Accessed 28.12.2019].

Reduction of the VAT rate to $7 \%$ for fruit and berry products will give impetus to the industry Ukrsadprom // https://growhow.in.ua/znyzhennya-stavky-pdv-do-7-na-plodovo-yagidnuproduktsiyu-dast-poshtovh-rozvytku-galuziukrsadprom/?fbclid=IwAR34w6B8wqOIDfMzGKxEqkQgldWNnSZnL2YkBcxGoFk6voczaxbfBeWbe0 [Accessed 28.12.2019].

DFS will simplify international trade through a one-stop shop // https://growhow.in.ua/dfs-cherez-yedynevikno-sprostyt-mizhnarodnu-torgivlyu/?fbclid=IwAR1RVK-

xVfMNvE5dVsOCdZ3eRn9xh6QJHjFgjywOd8HgG9KZQbil6or9iCg [Accessed 28.12.2019].

Ostap Semerak: "The Strategy for State Environmental Policy adopted until the year 2030 adopted in the first reading" // https://menr.gov.ua/news/32796.html?fbclid=IwAR248KU6BHKzxhxpGkkm_dbtovD0zW1nJNnBZal_nnbPXcmHl7QoewmYbo [Accessed 28.12.2019].

Ostap Semerak: "Ukraine, Georgia and Moldova will receive financial assistance from the EU for the development of the environmental // https://menr.gov.ua/news/32789.html?fbclid=IwAR1HVv-

LoTGGh6xBYLopfk1zhMTLc_6D6O8DCJoy_kQwpbNUOi4NTIbblGA [Accessed 28.12.2019].

Ecological consciousness in Ukraine and in the EU: top 5 similarities and differences // https://www.eurointegration.com.ua/articles/2018/09/24/7087297/?fbclid=IwAR3gJ_Cgn7P19 Iun3cuR5EOa1bIoS0NeXdLIEdqM7jutPo9sOAJEQyl8Kys [Accessed 28.12.2019]. 